\title{
Stigmina koyanensis - a new conidial fungus from Western Ghats of India
}

\section{Dubey $R^{*}$ and Sengupta $S$}

Botanical Survey of India, Western Regional Centre, Pune, Maharashtra, India

Dubey R, Sengupta S 2016 - Stigmina koyanensis - a new conidial fungus from Western Ghats of India. Plant Pathology \& Quarantine 6(1), 54-58, Doi 10.5943/ppq/6/1/8

\begin{abstract}
An interesting fungus collected during investigations of foliicolous fungi in Western Ghats of India is described and illustrated. Stigmina koyanensis sp. nov. is distinguished by having conidia with a pale apical beak.
\end{abstract}

Key words - biodiversity - microfungi - taxonomy

\section{Introduction}

Western Ghats is one of the 33 recognised ecologically sensitive zones in the world. It is situated in the southern west coast of the Indian peninsula and covers an area of about $160,000 \mathrm{~km}^{2}$. The pristine natural forests, microhabitats, and tropical warm humid climate that prevail in the Western Ghats support many rare and new forms of fungi (Dubey \& Moonambeth 2013 a, b, c, 2014). Koyana wildlife sanctuary, situated in Northern Western Ghats, covers an area of 423.55 $\mathrm{km}^{2}$ with elevations ranging from 600 to $1100 \mathrm{~m}$. During a mycological survey of conidial fungi from the dominating vegetation of Koyana Wildlife Sanctuary, an interesting species of Stigmina (Mycosphaerellaceae) was collected from dried leaves of Ficus sp. buried in moist soil and showed morphological differences from all previously described species (Annonymous 1989-2015). According to Mycobank and Index Fungorum databases 170 species of Stigmina have been reported. Three species, Stigmina fici Pagvi Singh, S. fici-elasticae Kapoor, and S. fici-mysorensis Muthappa have been reported on Ficus spp. The present species differs from other species in having a pale apical beak. The specimen is therefore described as a new species.

\section{Materials \& Methods}

\section{Isolates and morphology}

Samples of dried leaves were placed in paper and aluminium foil bags, taken to the laboratory, and prepared according to Castañeda-Ruiz (2005). Mounts were prepared in PVL (polyvinyl alcohol, lactic acid, and phenol). Photomicrographs were taken using a Nikon eclipse 50 i microscope connected to a Nikon DS- Fi 1 camera. Scanning electron microscopic images were captured using a Zeiss scanning electron microscope (Model EVO 18-12-97). The type specimen is deposited in Botanical Survey of India, Western Regional Centre, Pune. 


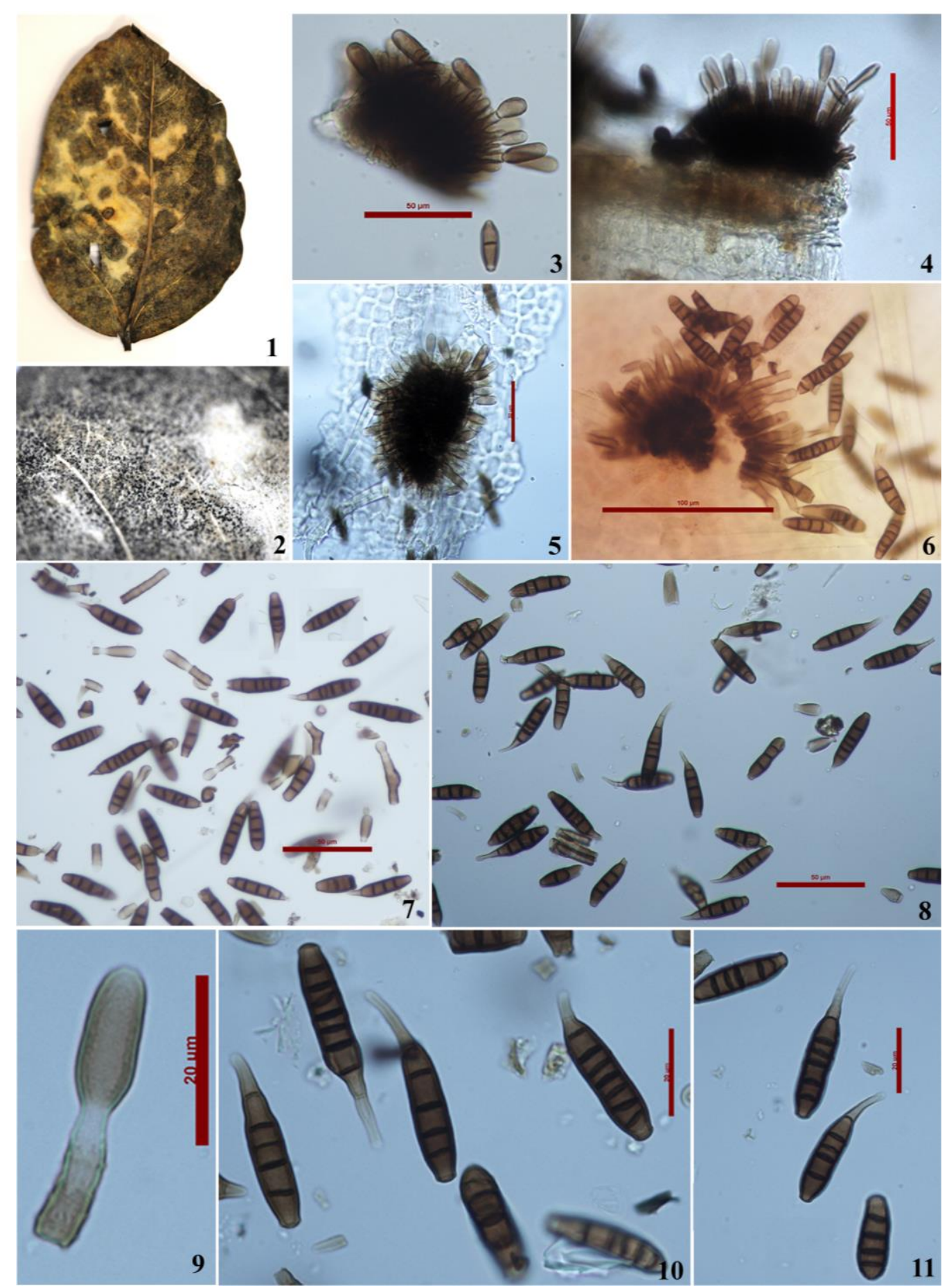

Figs 1-11 - Stigmina koyanensis sp. nov. - 1 Infected leaf of Ficus sp. 2 Punctiform colonies of S. koyanensis over the host leaf. 3-5 Stromata. 6 Conidiophores and conidia. 7-8 Conidia. 9 Conidiophores showing annellations. 10-11 Conidia with apical beaks. - Bars $-3-5,7-8=50 \mu \mathrm{m}$; $6=100 \mu \mathrm{m} ; 9-11=20 \mu \mathrm{m}$.

\section{Results}

Stigmina koyanensis Dubey Sengupta sp. nov.

Figs $1-17$

MycoBank: MB813869

Etymology - species named after the place of collection (Koyana Wildlife Sanctuary, Maharashtra, India).

Sporodochia on underside of dried and dead buried leaves, minute, punctiform, dark olivaceous brown, stromata 60-100 $\mu \mathrm{m}$ wide. Conidiophores cylindrical, straight or flexuous, rust 
coloured, up to $50 \mu \mathrm{m}$ long, 6-10 $\mu \mathrm{m}$ thick with up to 4 annellations. Conidia mid rust coloured with a pale apical beak, clavate, smooth, 3-7 septate, 22-60 $\mu \mathrm{m}$ long, beak up to $20 \mu \mathrm{m}$ long, $8-10$ $\mu \mathrm{m}$ thick in the broadest part, $4-5 \mu \mathrm{m}$ thick at the base.

Sexual state - Unknown.

Known distribution - Koyana Wildlife Sanctuary, Maharashtra, India.

Holotype - India, Maharashtra, Koyana Wildlife Sanctuary, on dried and buried Ficus leaves in soil, 13 Feb 2015, Rashmi Dubey, B.S.I. (W.C) Accession No. 134149.
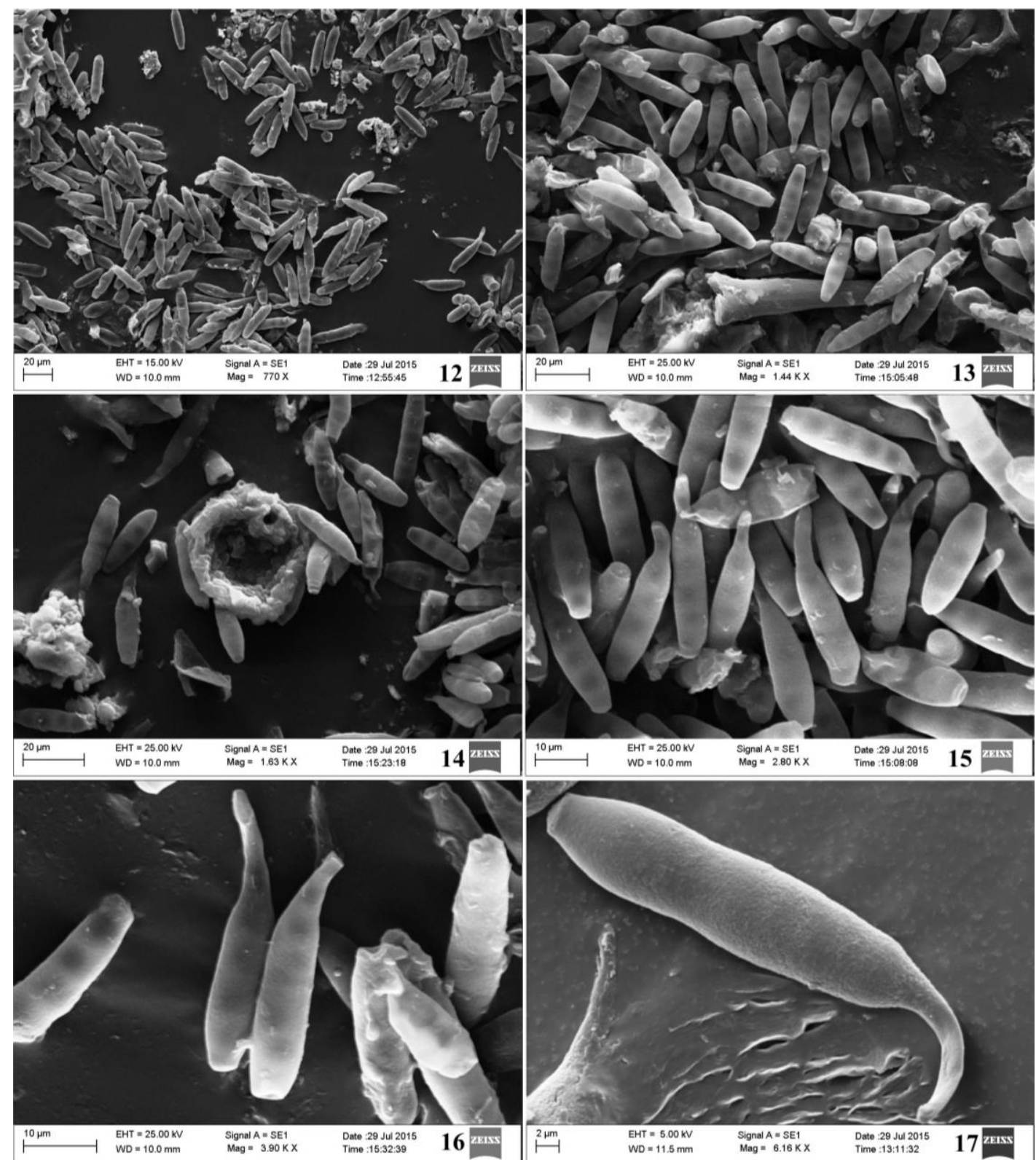

Figs 12-14 - SEM images of Stigmina koyanensis sp. 12-13 Conidia. 14 Stromata. 15-17 Conidia with prominent apical beaks.

\section{Discussion}

Six species of Stigmina have been reported on family Moraceae, and three species, Stigmina fici (Pagvi \& Singh 1966), S. fici-elasticae (Kapoor 1968) and S. fici-mysorensis (Muthappa 1973) have been reported on Ficus sp. from India (Bilgrami et al. 1979, 1981, 1991, Jamaluddin 2004). Conidia of Stigmina species reported on Ficus sp. are rough-walled and without a beak, whereas conidia of the new species are smooth with an apical hyaline beak. The present taxon also 
resembles $S$. phaeocarpa (Ellis 1959) in having conidia with a pale beak, but in S. phaeocarpa the beak is very long $(20-130 \mu \mathrm{m})$ and the conidia also have oblique septa, whereas in $S$. koyanensis the conidial beak is up to $60 \mu \mathrm{m}$ long and the conidia are without oblique septa.

\section{Key to Stigmina species reported on family Moraceae}

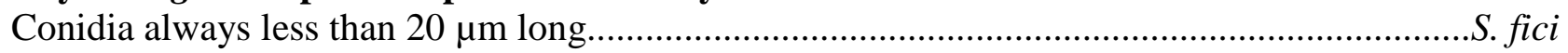

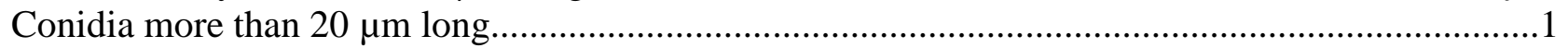

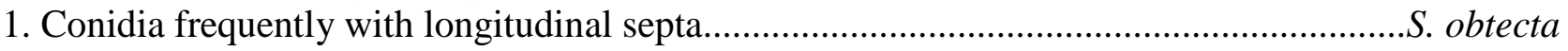

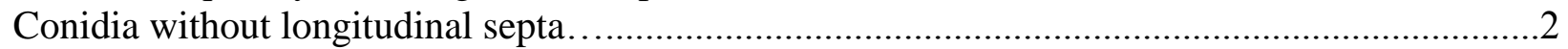

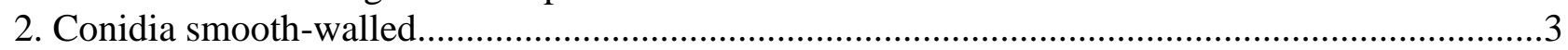

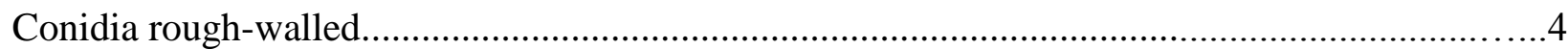

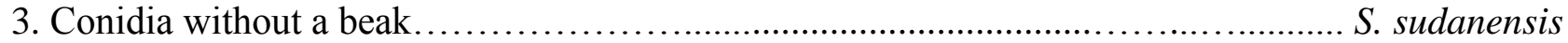

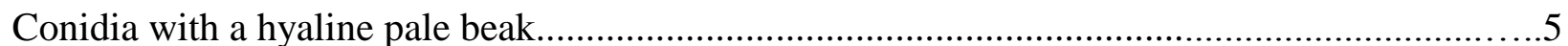

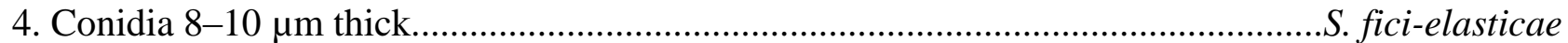

Conidia 11-12 $\mu \mathrm{m}$ thick............................................................................ ficus-mysorensis

5. Conidia with more than 7 septa............................................................................... . maculata

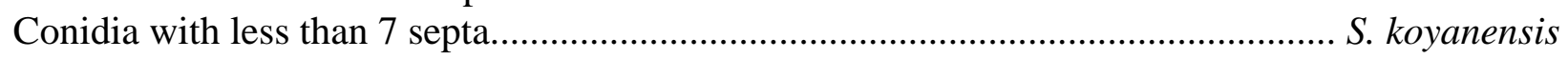

\section{Acknowledgements}

Authors thank Dr. Paramjit Singh, Director, Botanical Survey of India, for providing research facilities. They are also grateful to the Head of the office, Botanical Survey of India, Western Regional Centre, Pune, for his kind support and encouragement. Ministry of Environment and Forest, New Delhi, is acknowledged for financial assistance.

\section{References}

Anonymous 1989-2015 - Fungal Database Nomenclature and species identification. MycoBank. http://www.mycobank.org/Stigmina (accessed 31 July 2015).

Anonymous 2015 - The Index Fungorum database and web site. http://www.indexfungorum. org/Stigmina (accessed 31 July 2015).

Bilgrami KS, Jamaluddin, Rizwi MA. 1979 - The Fungi of India. Part I (List and References). Today and Tomorrow's Printers and Publishers, New Delhi. pp 467.

Bilgrami KS, Jamaluddin, Rizwi MA. 1981 - The Fungi of India. Part II (Host Index and Addenda). Today and Tomorrow's Printer and Publishers. New Delhi. pp 128.

Bilgrami KS, Jamaluddin, Rizwi MA. 1991 - The Fungi of India. Part III (List and References). Today and Tomorrow's Printer and Publishers, New Delhi. pp 798.

Castañeda-Ruiz RF. 2005 - Metodologíaen el estudio de loshongosanamorfos. 182-183. Anais do V Congresso Latino Americano de Micología. Brasilia.

Dubey R, Moonnambeth NA. 2013a - Kamalomyces mahabaleshwarensis sp. nov. (Tubeufiaceae) from the Western Ghats, India - Mycosphere 4, 760-764.

Dubey R, Moonnambeth NA. 2013b - Sawantomyces, a new hyphomycete genus from Western Ghats, India. Journal on New Biological Reports 2, 234-237.

Dubey R, Moonnambeth NA. 2013c - Custingophora ratnagiriensis sp. nov. a novel species of Custingophora from Konkan, India. NeBIO - An International Journal of Environment and Biodiversity 4, 31-32.

Dubey R, Moonnambeth NA. 2014 - Goosiomyces bambusicola - a new cheirosporous anamorphic species from Western Ghats, India. Current Research in Environmental \& Applied Mycology 4(2), 211-216.

Ellis MB. 1959 - Clasterosporium and some allied dematiaceae-phragmosporae. II. Mycological Papers 72, 1-75.

Ellis MB. 1976 - More Dematiaceous Hyphomycetes. C.A.B. Commonwealth Mycological Institute, Kew, Surrey, England. pp 507. 
Kapoor JN. 1968 - New microfungi from India. Transactions of the British Mycological Society 51(2), 328-333.

Muthappa BN. 1973 - Morphology of Stigmina ficus-mysorensis sp. nov. Transactions of the British Mycological Society 61(3), 602-605.

Pavgi MS, Singh UP. 1966 - Parasitic fungi from North India - VII. Mycopathologia et Mycologia Applicata 30(3-4), 261-270. 